\title{
Carbon Nanotubes Impregnated with Subventricular Zone Neural Progenitor Cells Promotes Recovery from Stroke [Corrigendum]
}

Moon SU, Kim J, Bokara KK, et al. Int J Nanomedicine. 2012;7:2751-2765.

The authors have advised Figure 5 on page 2760 is incorrect. Due to an error at the time of figure assembly the images for Figure 5B and 5F were duplicated. The authors did not pick this error up during the proof-reading stage of the publication. The correct Figure 5 is shown below.

The authors apologize for this error and advise that this does not affect the results of the paper.
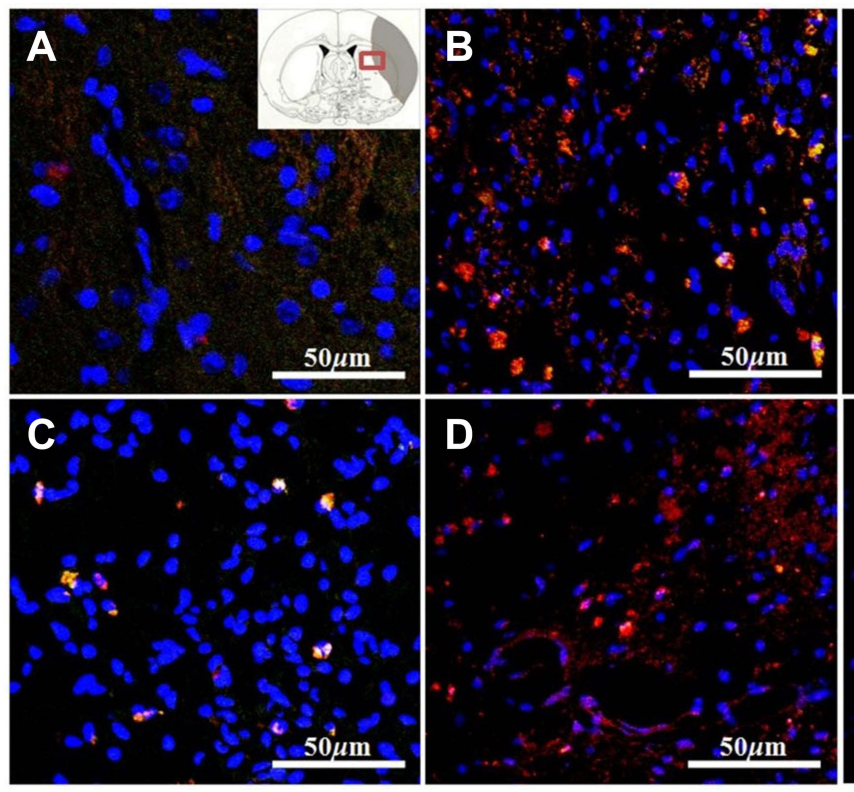
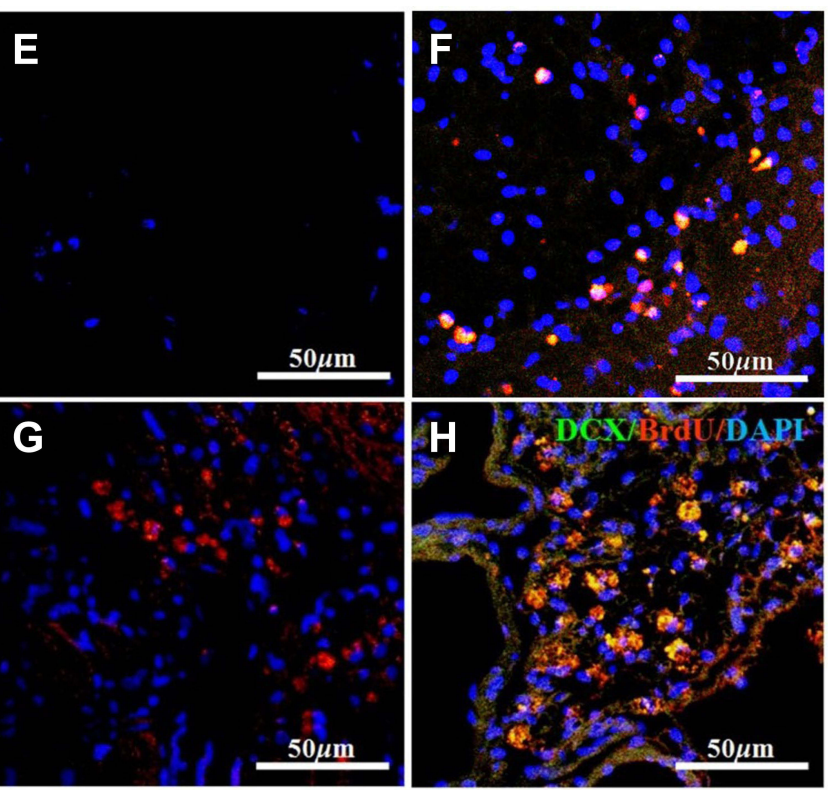

Figure 5 Doublecortin and bromodeoxyuridine staining was performed to detect the migrating exogenous subventricular zone neural progenitor cells in the hydrophilic or hydrophobic carbon nanotubes transplantation groups ( $\mathbf{A}$ and $\mathbf{D}) 3$ weeks or (E and $\mathbf{H}) 5$ weeks after middle cerebral artery occlusion injury. The images show (A and $\mathbf{E})$ the experimental control group (without subventricular zone neural progenitor cell transplantation), (B and $\mathbf{F}$ ) injury-subjected rats transplanted with subventricular zone neural progenitor cells, (C and $\mathbf{G})$ injury-subjected rats transplanted with hydrophilic carbon nanotubes impregnated with subventricular zone neural progenitor cells, and (D and $\mathbf{H}$ ) injury-subjected rats transplanted with hydrophobic carbon nanotubes impregnated with subventricular zone neural progenitor cells.

Notes: Doublecortin and bromodeoxyuridine double positive immunostained cells are indicated by yellow. Scale bars $=50 \mu \mathrm{m}$.

Abbreviations: BrdU, bromodeoxyuridine; DAPI, 4',6-diamidino-2-phenylindole; DCX, doublecortin.

\section{Publish your work in this journal}

The International Journal of Nanomedicine is an international, peerreviewed journal focusing on the application of nanotechnology in diagnostics, therapeutics, and drug delivery systems throughout the biomedical field. This journal is indexed on PubMed Central, MedLine, CAS, SciSearch ${ }^{\mathbb{R}}$, Current Contents ${ }^{\mathbb{B}} /$ Clinical Medicine,
Journal Citation Reports/Science Edition, EMBase, Scopus and the Elsevier Bibliographic databases. The manuscript management system is completely online and includes a very quick and fair peer-review system, which is all easy to use. Visit http://www.dovepress.com/ testimonials.php to read real quotes from published authors. 